\title{
Yahoo! And The Chinese Dissidents: A Case Study Of Trust, Values, And Clashing Cultures
}

Gerald Venezia, Hood College, USA

Chiulien C. Venezia, Frostburg State University, USA

\begin{abstract}
This case involves the global business ethics of two distinctly different cultures whose definition of human rights is embedded within their differing historical traditions. The Constitution of the United States guarantees individual rights for each of its citizens, including free speech and the right to petition the government. The People's Republic of China traces its roots to the ancient tradition of Confucius and the Mandate of Heaven that advocated the Emperor's responsibility to provide economic justice to instill social harmony. This perspective is echoed by the Communist's party of the PRC with its insistence on the prohibition of public dissent. How then should an American firm address these issues while remaining competitive in the global arena and should they be held responsible for abiding to foreign law? This case presents the ethical dilemma faced by democratic multinationals conducting business globally.
\end{abstract}

Keywords: Human rights, ethics, global business, Yahoo!, multinationals, China

\section{INTRODUCTION}

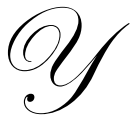

ahoo! is a $\$ 5.3$ billion-a-year company that provides Internet service worldwide. The company's purpose, as stated on its website, is: "powering communities to create indispensable experiences; built on trust." Yahoo! continues the same theme under its Company Overview: "Yahoo! powers and delights our communities of users, advertisers, and publishers - all of us united in creating indispensable experiences, and fueled by trust" (Yahoo website, 2008). In the company's own words, Yahoo! is "built on and fueled by trust" (Yahoo website, 2008). Yet what happens when a U.S. company such as Yahoo! conducts business outside the United States? Does the promise of trust "translate" to any language? Does the value of trust apply to any culture?

In 2002 and 2004, Chinese citizens, Wang Xiaoning and Shi Tao, were arrested, prosecuted, convicted, and sentenced to prison for 10 years for e-mailing pro-democracy views from information provided by Yahoo! Corporation. The wife of Xiaoning sued Yahoo! in the United States courts under the Alien Tort Claims Act and the Torture Victim Protection Act. The company also confronted a "firestorm" of criticism for aiding abetting human rights abuses. Yahoo! consequently faced what has become a major concern for all businesses that decide to engage in the global economy and to remain competitive in the global arena - the clash of culture and legal and cultural values. In particular, the Internet permits freer access to information and, accordingly, allows dissidents within China and other countries to communicate, although at great risk; yet legally compelling a company such as Yahoo! to abide by the rules of a foreign government, which may be a one-party dictatorial state, concomitantly meaning that a U.S. company such as Yahoo! may provide information about Internet users that could lead to their identification, imprisonment, and even torture.

China is the fastest growing Internet market in the world, representing over 162 million users, who either own a computer or use one from cyber or Internet cafés. This number represents about 12.3 per cent of the population. With 1.3 million Chinese websites, and 19 per cent of users having their own blogs, Yahoo!, in order to maintain a sustainable competitive advantage, decided to enter the Chinese market (Tao, 2007). 


\section{E-BAY FUELS GLOBAL COMPETITION ENTERING THE CHINA MARKET}

Entrepreneur Meg Whitman initially saw the opportunity to expand eBay into China in the 1990's. After technical difficulties delayed her entry into Japan in 1999, Yahoo! took advantage of that situation, and cornered the market on e-commerce, and soon became the second largest e-commerce market in the world. Confronting such a disadvantage, eBay pulled out in 2002. After her disappointment in Japan, Ms. Whitman turned her attention to China. China was not without competition, however. Jack Ma, an early pioneer in China's Internet, provided information on China's industrial companies during the mid-1990's, and launched Alibaba.com in 1999. Alibaba.com was a business-to-business site that complemented his Taobao, which in Mandarin Chinese translates to "searching for treasure," a year later (Powell and Ressner, 2005). Meg Whitman chose to ignore Taobao-Alibaba, and thus purchased EachNet in 2002. EachNet was a Chinese e-commerce company established by a Harvard Business School graduate in 1999 that mirrored eBay. By August 8, 2005, the competition between Alibaba and eBay took on a new dimension when Jack Ma announced he was selling a 40\% stake in his company to Yahoo! for one billion U.S. dollars. The merger gave Alibaba strength in business to business, consumer sales, online payments and search (Powell and Ressner, 2005).

\section{YAHOO!'S DECISION TO PLACE SERVERS ON CHINESE SOIL}

Yahoo! entered the Chinese market in 1999 through Yahoo! Holdings (Hong Kong), Ltd as Yahoo! China. Yahoo! HK, a wholly owned subsidiary of Yahoo! Inc, was the business entity, and/or agent of Yahoo Inc., and was responsible for operating and managing Yahoo! China until the strategic partnership with Alibaba.com in October 2005. With the partnership, Yahoo! Inc merged the operations of Yahoo! China into Alibaba, who maintained exclusive rights to use the Yahoo! brand in China.

Unlike Google, which kept personal information outside China through G-mail and Blogger, or Microsoft which refused to host Hotmail on servers inside the Peoples Republic of China, Yahoo! relinquished control of their e-mail to servers located within China, thus making them applicable to Chinese law (Human Rights Watch, 2006). According to court documents, sometime in 2002, Yahoo! voluntarily signed the Internet Society of China's "Public Pledge on Self-Discipline for the Chinese Internet Industry." By signing the Public Pledge, Yahoo! Inc. voluntarily agreed to help monitor and censor electronic communication that could jeopardize state security or disrupt social stability (Sklar, 2007).

Information of any kind within China is tightly controlled by the government. Despite its transition from a "command economy" to a "mixed market" economy, the Chinese Communist government still firmly controls the flow of information through all forms of media, including the Internet. The Internet is controlled through five supervisory bodies as well as a host of Internet police (Tao, 2007). Their tasks are to supervise and manage online information circulating on the Internet and to monitor public opinion. If websites post information deemed "offensive" to the government, they are sent a warning, fined, or the offending site is removed. The government authorities also disseminate stories written by the government that the government feels are important and worthy.

Of particular relevance to this case is the State Secrets Law. A "state secret" is broadly defined. In fact, the State Secrets Bureau has wide discretion in determining what qualifies as a "state secret." The government also has the power to retroactively determine that information is a state secret. If an individual is convicted of providing overseas individuals or organizations with state secrets over the Internet, they face criminal law sanctions, including the death penalty (Zittrain and Palfrey Jr., 2005). According to U.S. Representative Tom Lantos, the term "state secret" is used to concoct a case to persecute political activists (Lantos, 2007).

\section{ETHICS AND GLOBAL COMPETITION}

Wang Xiaoning was the son of high ranking cadres in China, but early on he found himself at odds with the Communist government. He participated in the Tiananmen Square protests where he was shot and injured. As a result, he was labeled a "reactionary." Afterwards he wrote an essay entitled, "A Political Manifesto of Democratic Ideology in China" which he sent out of the country. His possessions were confiscated by the Public Security Bureau shortly following the essay. This seizure did not deter him. He went on-line and sent essays to Internet 
journals espousing democratic values. He also created electronic journals through Yahoo! Groups. By August 2001, Wang had distributed 25 editions of "Current Political Commentary" through Yahoo! Groups. Aware of the political content, Yahoo! administrators prevented him from disseminating any further essays in Yahoo! Groups. Barred from Yahoo! Groups, he then e-mailed the next six editions through private e-mail addresses. He also sent commentary to "Democracy Forum," an overseas website advocating democratic reform and criticizing the government repression of peasants and trade union leaders (Kwan, 2006).

In September 2001, Wang's home was raided by the Public Security Bureau, and his computer and related files were confiscated. He was formally charged with incitement to subvert state power under Articles 105 and 106 of the PRC Criminal Law. He was also accused of endangering state security. Wang was sentenced to ten years in prison in July of 2003. The Supreme People's Court rejected his appeal in December of 2004 (Kwan, 2006).

Without the aid of Chinese journalists or the legal profession, Wang's wife, Yu Ling, flew to the United States and sued Yahoo!. She contended that Yahoo! willingly provided the Chinese government with private e-mail addresses, user ID numbers, and other identifying information that led to her husband's imprisonment and torture. The case was filed by Morton H. Sklar, Executive Director of the World Organization for Human Rights USA in Washington D.C. (Sklar, 2007); and named as defendants Yahoo! Inc (a Delaware Corporation), Yahoo! Holdings (Hong Kong), Ltd., a foreign subsidiary of Yahoo! and Alibaba.Com, Inc. (a Delaware Corporation) actionable under the Alien Tort Stature and the Torture Victim Protection Act on behalf of Wang Xiaoning, Yu Ling, and Additional Presently Unnamed and to be Identified Individuals (Shi Tao, 2007). Human rights lawyers and activists long have claimed the Alien Tort statute grants legal jurisdiction to U.S. courts over acts abroad that violate "international norms." Written in 1789 by the Founding Fathers, the statute has rarely been used until the 1980's. Since then, nearly two dozen claims have been filed against businesses. Rutgers University professor Beth Stephens, a specialist in human rights law, succinctly explained: "The law says you can't just close your eyes. You're negligent if you should have known" (Cha and Diaz, 2007 p.4). The claim also accuses the defendants of violating the California Business and Professional Code as well as United States law pursuant to the Electronic Communications Privacy Act (Cha and Diaz, 2007).

The additional plaintiff named in the lawsuit was Shi Tao. Shi Tao was arrested in 2004 on similar charges. Shi was a reporter for China's Contemporary Business News. During a staff meeting, a memo sent from the Chinese government warned all journalists of the possibility of civil unrest surrounding the $15^{\text {th }}$ anniversary of the 1989 Tiananmen Square "incident." The government strongly impressed upon the journalists to maintain "social harmony" by not interfering. The government was concerned that overseas Chinese would return to China to protest, thereby causing unrest. Shi Tao copied the memo and sent it via a Yahoo! e-mail account to a U.S.-based website called Asia Democracy Foundation. The government discovered the leaked memo, and consequently asked Yahoo! for the IP address. Yahoo! handed over the information to the Chinese authorities (Lewis, 2007). As a result, Shi Tao was arrested, tried, convicted, and sentenced to 10 years in prison for the crime of "revealing state secrets." Shi Tao's plight was unknown in the West until the Paris-based Reporters Without Borders released court documents outlining Yahoo! HK's role in identifying Tao to the Chinese authorities (Marquand, 2005).

\section{AMERICAN VALUES AND GLOBAL BUSINESS}

The lawsuit immediately drew the attention of the United States Congress, which began an investigation into Yahoo! and its role in the punishment of both human rights activists. The testimony of Michael Callahan, Senior Vice President and General Counsel for Yahoo! Inc., was given before the Congressional Subcommittees of Africa, Global Human Rights and International Operations, and Asia and the Pacific on February 15, 2006. Mr. Callahan addressed the Committee by stating that the issues involved were larger than any one company, or any one industry. All businesses face the same struggle between "American" values and the laws that all global businesses must obey. He outlined the positive influence of the Internet in China. For example, when the Chinese government suppressed information on SARS, communications spread through the Internet, alerting Chinese people and the world to the severity of the epidemic. The Chinese government was thus pressured to be more transparent and responsive. Human Rights Watch also reported how online protests about the death of a college student led to abolition of the law used to detain him. The 2002 RAND Corporation report concluded the Internet in China has allowed dissidents to communicate quickly and with ease (Callahan, 2006). 
Concerning Shi Tao, Mr. Callahan claimed Yahoo! China in Beijing supplied the information, not Yahoo! HK. He insisted Yahoo! Inc. never knew specific details pertaining to the Chinese government's request for information. Furthermore, law enforcement agencies in China and elsewhere, he pointed out, do not inform businesses why they demand information. Crucial to his case, he therefore claimed that Yahoo! in most cases does not know the identity of its uses, since subscribers often use aliases. He also made a point of reminding the Committee members that foreign companies in the United States also must comply with U.S. law enforcement when asked for information. Failure to comply in China meant employees of Yahoo! China were subject to criminal charges or imprisonment. U.S. companies in China thus face a very difficult choice: either comply with the Chinese law, or leave the Chinese market. Lastly, he stressed that Yahoo! China and Yahoo! Hong Kong operated independently of one another, and as such never exchanged information (Callahan, 2006).

\section{CONCLUSION AND SUMMARY}

Eighteen months later the Committee convened and Chairman of the Committee, Tom Lantos, responded by accusing Mr. Callahan of giving false information, but stopping short of charging him with perjury. He disputed the fact that Yahoo! had no knowledge concerning the reason the Chinese government wanted information concerning Shi Tao. The Committee obtained a copy of the original request for information published by the San Francisco-based Dui Hua Foundation, to wit:

\section{Beijing State Security Bureau Notice of Evidence Collection}

[2004] BJ State Sec. Ev. Coll. No. 02

Beijing Representative Office, Yahoo! (HK) Holdings Ltd.:

According to investigation, your office is in possession of the following items relating to a case of suspecting illegal provision of state secrets to foreign entities that is currently under investigation by our bureau. In accordance with Article 45 of the Criminal Procedure Law of the PRC, [these items] may be collected. The items for collection are:

Email account registration information for huoyan1989@yahoo.com.cn, all login times, corresponding IP addresses, and relevant email content from February 22, 2004 to present.

\section{Beijing State Security Bureau (seal) \\ April 22, 2004}

Yahoo claimed this information was all a matter of internal "miscommunication." Mr. Lantos, on the other hand, accused Yahoo! of "inexcusable negligent behavior at best, and deliberately deceptive behavior at worst" (Lantos, 2007).The Chairman continued to emphasize the importance of high-tech companies such as Yahoo! to the American, as well as the global, economy and underscored their contribution to changing the world we live in, which is all the more reason why American companies should not be playing an integral role in China's brutal and repressive police state, he emphasized. Yahoo!, however, insisted the lawsuit was "political" in nature, and one that challenged the Chinese government as having no place in U.S. courts. "Free speech rights, as we understand them in the United States, are not the law in China. Every sovereign nation has a right to regulate speech within its borders" (Richards, 2007). Those who use Yahoo! China e-mail knowingly assume the risk of violating Chinese law. Although Yahoo! does not condone the suppression of rights and liberty in China, the company asserts it has no control over the sovereign Government of the People's Republic of China, including their laws and the enforcement thereof.

Shortly after the Congressional committee hearing, Yahoo! settled the lawsuit. Jerry Yang, the Yahoo! chief executive, agreed to provide financial, humanitarian, and legal support to the families of the dissidents, as well as to set up a fund to assist other political dissidents and their families (Letzing, 2007). 


\section{DISCUSSION QUESTIONS}

1. By placing their servers off shore, Google and Microsoft were not liable to the PRC's laws. Should Yahoo have done the same?

2. Was Tom Lantos and the US Congress irresponsible in applying American values to foreign countries impeding US companies ability to compete on the global playing field?

3. Should Yahoo! be held responsible for the actions of PRC citizens who knew they were violating the law?

4. What of the question of "trust"? Should Yahoo!'s mission statement of trust extend to the global community of users?

\section{AUTHOR INFORMATION}

Gerald Venezia, DPA, is an adjunct assistant professor with the department of Global Studies at Hood College. Dr. Gerald Venezia spent three years teaching in Asia researching issues pertaining to East Asia and globalization before returning to the United States. His areas of research are in comparative government and politics and the social, economic and political affects of globalization.

Chiulien C. Venezia, DBA, CPA, has been teaching Accounting since 1992. She is an assistant professor of Accounting at Frostburg State University, Maryland. Her research interests include cross-cultural ethics, earnings management, and financial performance. She has published papers in the International Business \& Economics Research Journal, the Journal of American Academy of Business, Cambridge, and Journal of Nan Tai College.

\section{REFERENCES}

1. Beijing State Security Bureau Notice of Evidence Collection, April 2004. Available on the Internet at http://www.duihua.org/media/news/070725_ShiTao.pdf

2. Cha, A. E. \& Diaz, S. ( 2007). Washington Post Foreign Service. Available on the Internet at http://www.washingtonpost.com/wp-dyn/content/artical.2007/04/18/Ar2007041802510_pdf.html

3. Callahan, M. ( 2006). Testimony of Michael Callahan, Senior Vice President and General Counsel, Yahoo! Inc. Before the Subcommittees on Africa, Global Human Rights and International Operations, and Asia and the Pacific. Available on the Internet at http://www.nytimes.com/packages/pdf/business/yahoostatement.pdf

4. Human Rights Watch team (2006). "Race to the Bottom", Corporate Complicity in Chinese Internet Censorship, Chapter IV, Volume 18, No. 8(c ).

5. Kwan, V. (2006). Prisoner Profile: Wang Xiaoning. Available on the Internet at http://www.hrichina/public/PDFs/CRF.3.2006/CRF-2006-3_wangxiaoning.PDF

6. Lantos, T. (2007). Statement of Chairman Lantos at hearing, Yahoo! Inc.'s Provision of False Information to Congress. Available on the Internet at http://foreignaffairs.house.gov/press_print.asp?id=446

7. Lewis, W. (2007). Yahoo and the Great Firewall of China, Columbia Spectator online edition. Available at http://www.columbiaspectator.com

8. Letzing, J. (2007). Yahoo settles with jailed Chinese dissidents, Marketwatch. Available at http://www.marketwatch.com/news/story/yahoo-settles-jailed- Chinese-dissidents/story

9. Marquand, R. (2005). Yahoo, Chinese police, and a jailed journalist, The Christian Science Monitor. Available at http://www.csmonitor.com/2005/0909/p01s03-woap.html

10. Richards, J. (2007). Yahoo!: we did not assist torture in China, Times Online. Available at http://technology.timesonline.co.uk/tol/news/tech and-web/the web/article2340803.ece

11. Powell, B. \& Ressner, J. ( 2005). Why eBay Must Win China, Time Magazine

12. Sklar, M. ( 2007). Wang Xiaoning, Yu Ling, and Additional Presently unnamed and to be identified individuals, Plaintiffs, v Yahoo!Inc., a Delaware Corporation, Yahoo! Holdings (Hong Kong), Ltd., a Foreign Subsidiary of Yahoo!, Alibaba.com, Inc, a Delaware Corporation, and other presently unnamed and to to be identified individual employees of said corporations, defendants. Complaint for Tort Damage. United States District Court, Northern District of California, Case No.: 4:2007cv02151. Available at http://blog.wired.com/27backstroke6/files/yu_yahoo_complaint.pdf 
13. Tao (2007). China: Journey to the heart of Internet Censorship, Investigative report - October 2007. Reporters without Borders. Available at http://www.rsf.org/IMG/pdf/Voyage au_coeur_de_la_censure_B.pdf

14. Yahoo! website (2008). http://www.yahoo.com

15. Zattrain, J. L. \& Palfrey, J. G. Jr. (2005). Internet Filtering in China in 2004-2005: A Country Study. OpenNet Initiative. Available at http://opennet.net/sites/opennet.net/files/ONI_China_Country_Study.pdf

\section{NOTES}

